\title{
LANGUAGE PORTFOLIO FOR BUILDING LINGUISTIC COMPETENCE IN ESP SPEAKING IN STUDENTS' INDEPENDENT WORK
}

\author{
Andriy Kotlovskiy, Natalia Mykytenko, Andriana Onufriv, Maryana Salamakha \\ Ivan Franko National University of Lviv, Lviv, Ukraine \\ natusiamykyt@gmail.com
}

\begin{abstract}
The study shows that language portfolio is an effective tool which is applied in students' independent work. We aimed to survey students' views on the usage of language portfolio; to define the types of students' autonomy with teacher's guidance that contribute to successful acquisition of lexical and grammatical competences within students' independent work; to give recommendations to teachers about using language portfolio for building lexical and grammatical competences in ESP speaking. Thus, a mixed research design was employed. The qualitative research design relied on collecting data about students' attitude to using language portfolio as a tool of building their lexical and grammatical competences in ESP speaking within their independent work. The quantitative research design was focused on interpreting the results and suggesting recommendations regarding students' independent work in ESP learning. The research was held at Ivan Franko National University of Lviv during December-February of 2019-2020 academic year. The total number of full-time second-year students who took part voluntarily was 250. Also, five ESP teachers participated in the survey. Within the context of the study, the questionnaire was designed to identify students' attitude towards learning aims, ways to achieve them, type of teacher's guidance, practicability of keys, instructions, range of suitable techniques. The findings show that the students prefer relative autonomy and half-autonomy with a firm and relatively firm teacher's guidance to follow while acquiring lexical and grammatical competences in ESP speaking. Most students admit that language portfolio is an effective tool which promotes significant progress in their lexical and grammatical competences in ESP speaking.
\end{abstract}

Keywords: lexical and grammatical competence; speaking; independent work; autonomy; language portfolio.

\section{Introduction}

The expansion and intensification of international ties of Ukraine in the world intensifies the significance of mastering the English language by future specialists of Economics. The successful acquisition of English for specific purposes (ESP) is accompanied with the process of building lexical and grammatical competences in speaking. It is acknowledged that these competences furnish correct presentation of own utterances and understanding interlocutors' speech. In view of the tendency towards the reduction of classroom ESP learning hours for the students majoring in Economics, independent work becomes crucially important, since it gives an opportunity to optimise the learning process by extending its time frames.

Lexical and grammatical competences, as the components of linguistic one, belong to the main competences within a foreign language. While building lexical and grammatical competences in speaking of prospective economists it is essential to focus on lexical and grammatical knowledge, skills, awareness, and speech skills in speaking. Lexical knowledge encompasses knowledge of sound and graphical forms of a word, reading rules, semantics, ability to have synonyms, antonyms, stylistic and sociocultural colouring, types of vocabularies, similarities and differences in lexical systems of native and foreign languages. The knowledge of grammar is instrumental to build new words by morphological transformation of known words, to combine lexemes with the sentence, to use words following the content of the sentence.

An ability to learn on one's own is a basic human competence. It stands to reason that the constructivist philosophy in education was largely advocating a student-centred approach in teaching methodology (Von Glaserfeld, 1989). Student-centred learning promotes incorporating students' independent work into learning process. White (2008) points out that "a fundamental challenge of independent language learning is for learners to develop the ability to engage with, interact with, and derive benefit from learning environments which are not directly mediated by a teacher" (p. 3). In this case, the basic principles of independent language learning involve "optimising or extending learner choice, focusing on the needs of individual learners, not the interests of a teacher or an institution, and the diffusion of decision-making to learners" (p. 3).

Organisation of independent work implies an external teacher's guidance and student's selfmanagement of own learning and informative activity. The efficiency of independent work depends on correctly determined learning aims, objectives, choice of tools and ways to solve problems, organisational aptitudes and students' motivation. External guidance of a teacher can be firm, relatively firm, relatively flexible and flexible. The flexibility of guidance is measured by the extent of teacher's participation and influence on the independent work (Zadorozhna, 2011, p. 11-14).

Kotlovskiy, A., Mykytenko, N., Onufriv, A., Salamakha, M. (2020). Language portfolio for building linguistic competence in ESP speaking in students' independent work. Advanced Education, 15, 20-24. DOI: 10.20535/2410-8286.200750 
Independent teacher's guidance of ESP learning activity implies the development of learning autonomy. Language learner autonomy as the ability to take "charge of one's own learning" (Holec, 1981, p. 3) involves such areas of learning as "determining the goals; defining the contents and progressions; selecting methods and techniques to be used; monitoring the procedure of acquisition properly speaking; evaluating what has been acquired" (Holec, 1981, p. 3). Oxford (2015) summarises that autonomous learners are "self-regulated, emotionally intelligent, resilient, psychologically engaged, self-determined, existentially free, and effective" (p. 59).

Autonomy is viewed from different perspectives in the language learning. In particular, it can be considered as an essential goal of learner training programmes (Chan, 2003), a component of self-directed learning (Hawkins, 2018). Cooker (2012) argues that the formative (self-)assessment practices can help develop autonomous learners. A new learner autonomy continuum, the individual-competitive-collaborativeautonomous learning continuum, grading the progress of the learner in autonomous learning practices, is suggested by Blidi (2017). The use of technologies in the learning process is recognised to be able to foster students' autonomous learning (Wach, 2012). Therefore, autonomy has to be an inseparable part of ESP learning.

In addition, autonomy can be presented by various levels: relative autonomy, half-autonomy, partially dependent autonomy, conditionally complete autonomy (Tambovkina, 1998, p. 84-85; Kamenskaia, 1999, p. 36; Zadorozhna, 2011, p. 14). The levels of autonomy are correlated with appropriate guidance methods. Tambovkina (1998) differentiates two levels: relative autonomy and half-autonomy (p. 84-85). Relative autonomy relates to teachers' firm guidance of students' individual work that lies in the provision of keys, instructions, to monitor learning and informative activity, control students' current performance and check their progress. Half-autonomy corresponds with teachers' relatively firm guidance and implies joint outline of aims and strategies, execution of assignments with indirect teacher's guidance, but a student is free to choose one's own techniques (Tambovkina, 1998, p. 84-85). In the conditions of ESP learning, relative autonomy and half-autonomy are dominant.

Among the effective tools applied in independent work, language portfolio received its recognition. Language portfolio is an ongoing, interactive assessment that actively involves both the teacher and the student in the process of learning (Delett, Barnhardt, Kevorkian, 2001, p. 560); is known as "a powerful vehicle for promoting both student engagement and voice in the learning process" (Belgrad, Burke, Fogarty, 2008 , p. 2-3); is considered as learners' reflection type of professional activity and competitiveness which leads to self-assessment and self-development (Golubeva et al., 2019, p. 545; Zadorozhna, Datskiv, Levchyk, 2018, p. 66); demonstrates "the achievement and progress of students with special needs" (Belgrad, Burke, Fogarty, 2008, p. 2). "While portfolios can and do become important collections of key "artefacts" that remind students of their growth over time and of their accomplishment of learning standards, they also provide a deep, rich anthology of learning evidence" (Belgrad, Burke, Fogarty, 2008, p. 2). It is proved that the portfolio practice has had positive effects on reading, writing and listening skills of students (Demiral \& Duman, 2015, p. 2639). Thus, language portfolio is a collection of the students' effort, progress and success in foreign language learning. Taking into account a wide functionality of language portfolio mentioned in the researches above, we attempt to integrate selected aspects of language acquisition (vocabulary, grammar in speech production) under the umbrella of language portfolio in ESP independent work.

\section{Research aims}

Thus, in this paper, the following aims were set:

- to survey students' views on the usage of the language portfolio; to define the types of students' autonomy with teacher's guidance that contribute to the successful acquisition of lexical and grammatical competences in the context of the independent work;

- to give recommendations to teachers about using language portfolio for building lexical and grammatical competences in ESP speaking.

\section{Methods}

\section{Research Design}

In the study, a mixed research design was employed. The qualitative research design relied on collecting data about students' attitude to using language portfolio as a tool of building their lexical and grammatical competences in ESP speaking within their independent work. The quantitative research design was focused on interpreting the results and suggesting recommendations regarding students' independent work in ESP learning. 


\section{Research Sample}

The students majoring in Economics in Ivan Franko National University of Lviv participated in the survey during the third semester of 2019-2020. The total number of full-time second-year students who took part voluntarily was 250 . Also, five ESP teachers participated in the survey.

\section{Research Instruments and Procedures}

In the survey, a questionnaire was used which focused on defining aims, ways to achieve them, type of teacher's guidance, practicability of keys, instructions, range of suitable techniques while building lexical and grammatical competences of economics students in speaking. It contained seven closed-ended questions with two variants of answers that could be chosen by students. The questionnaire consisted of the following questions:

1. You prefer defining aims, strategies and ways to achieve them during the independent work

A. together with the teacher

B. individually

2. You prefer to perform exercises and assignments

A. under indirect teacher's guidance (partial autonomy)

B. individually (relative autonomy)

3. You prefer when performing assignments on building lexical and grammatical competences.
A. to have keys
B. not to have keys

4. You prefer when performing exercises on building lexical and grammatical competences.
A. having an instruction and a sample answer
B. having an instruction without a sample answer

5. You prefer choosing techniques to solve learning assignments
A. under immediate teacher's control
B. individually.

6. Do you like compiling language portfolio?

A. Yes

B. No

7. Do you feel that your lexical and grammatical competences in speaking are improving due to language portfolio?
A. Yes
B. No

\section{Data Analysis}

There were two stages in the data analysis process. First of all, we determined the students' views on the usage of language portfolio in their independent work on the basis of their answers to the questionnaire. Secondly, the results were interpreted and the recommendations to teachers were outlined.

\section{Results}

Testing 250 second-year students of Economics has shown a positive attitude to the usage of language portfolio in students' independent work.

When answering the first question, $65 \%$ of students stated that they preferred defining aims, strategies and ways to achieve them together with the teacher during independent work. At the same time, $35 \%$ of respondents wanted to do it individually. Thus, one third of our students are independent and self-directed learners while two thirds of them are not yet ready to take full responsibility for their learning.

$75 \%$ of respondents admitted that they preferred to perform exercises and assignments under indirect teacher's guidance and only $25 \%$ of respondents - individually. Preference for indirect teacher's guidance indicates that students are more inclined to enjoy freedom and independence in their foreign language learning. Students become motivated to find their learning pathway and face new challenges and opportunities while learning the English language. Teacher's participation is supposed to remain implicit.

Most respondents (68\%) appreciated the availability of keys to check their answers after performing assignments and exercises striving to build their receptive and reproductive skills. Nevertheless, 32\% of respondents did not need any keys. It indicates that students are confident in their language skills and they are sure in the correctness of their answers.

Also, $62 \%$ of respondents wanted to have instructions and sample answers to follow while building lexical and grammatical competences. Availability of instruction, especially in independent work, fosters the 
acquisition of skills. More than one third (38\%) of the respondents prefer doing exercises without any samples.

$53 \%$ of students prefer a free choice of techniques to perform learning assignments. It implies that the comprehension of new challenges and opportunities, which independent work presents, is going to trigger creation and transcendence in students' motivation. Moreover, it indicates that the majority of the respondents show their desire to find effective technological tools (apps, software online chats and video chats). Students are more confident and relaxed using technologies while learning, consolidating and practising lexical and grammatical materials.

We find it positive that $60 \%$ of students approve language portfolio, especially in view of the fact that initially the students were reluctant to keep a record of their progress in learning, since it requires selfdiscipline, time and persistence. The comprehension of the aims, ways to achieve them and the elaboration of learning strategies helped the students face the challenge and take responsibility for their individual learning. The students were inspired by an opportunity to define their ultimate learning aims and achieve them gradually.

Most respondents (75\%) admit that the development of their lexical and grammatical competences in speaking is attributed to language portfolio. One fourth of respondents $(25 \%)$ are not sure that the language portfolio can improve their lexical and grammatical competences in speaking. However, we assume that a wide range of assignments, exercises and activities, presented in language portfolio, can be beneficial for all students.

\section{Discussion}

Several issues for the discussion have emerged. The first issue deals with self-management in independent work that entails the development of students' learning autonomy. Students are engaged in planning and management of their independent work that is connected to setting the aims and objectives, pursuing new learning challenges and opportunities. According to the questionnaire, it is clear that students admit that they have problems with setting intermediate aims concerning the vocabulary (economic terms) and range of grammatical materials that are necessary to achieve B2 language proficiency level. A review of the results testifies that most respondents lack the basic "theoretical" knowledge of the framework of the English language (syntactical structures, vocabulary use, semantics etc.). Consequently, teachers can equip students with a toolkit that encompasses cognitive, metacognitive, memorising and communicative strategies.

The second issue is connected with the type of teacher's guidance in students' independent work. Effectiveness of students' independent work depends on teacher's participation in and influence on independent work. The students' answers that they prefer firm and relatively firm teacher's guidance. Students are more confident when the teacher facilitates planning and management of their independent work implicitly, but at the same time monitors and controls student's performance. Most students prefer having keys and instructions while doing assignments on building lexical and grammatical competences. Based on the questionnaire conducted with the students we came to the conclusion that it is appropriate for teachers to apply firm and relatively firm guidance of students' independent work and to permit relative autonomy and half-autonomy to students when developing lexical and grammatical competences in speaking.

The third issue is concerned with the choice of methods that foster the development of learning autonomy while building lexical and grammatical competences in speaking. As evidenced by the results of our research, one of such methods in teaching English to students majoring in Economics is language portfolio which boosts student's cognition, motivation and responsibility. The answers to the questionnaire suggest that it is expedient to introduce both relative autonomy and half-autonomy. At the introductory stage of independent work, it is proper to provide keys, instructions, monitoring of learning activity under the condition of relative autonomy. The following stage implies students' collaboration with the teacher in setting the aims and defining strategies, performance of assignments by students under the indirect teacher's guidance in the condition of half-autonomy.

According to Belgrad, Burke, Fogarty (2008), learning portfolios can be "designed to accommodate all students' diversity and they allow students to demonstrate their individual learning and achievement through a wide variety of authentic learning situations" (p. 8). We find adopting language portfolio to the integrated teaching of lexical and grammatical competences in speaking while students' independent work quite fruitful. While creating personal language portfolios, it is recommended that students classify lexical and grammatical material by organising semantic graphs within thematic fields, completing tables, drawing charts, mappings; create dialogues using professional terminology; keep reflexive journals of their own 
learning progress, achievements and failures. These exercises, assignments and activities should be aimed at building and developing lexical and grammatical receptive and reproductive skills in teaching oral communicative competence.

Having adopted language portfolio to the integrated teaching of lexical and grammatical competences in speaking, we found that it can be used as an effective tool in students' independent work. We found that students should have freedom when learning the English language, but at the same time, it is advisable to provide firm and relatively firm teacher's guidance within relative autonomy and half-autonomy.

\section{Limitations}

It is evident that students' attitudes to the use of language portfolio in independent work were positive. However, since this study was limited only by the participants of Ivan Franko National University of Lviv in Ukraine, further and larger-scale researches may be necessary before any generalisations are made.

\section{Conclusions}

Student's independent work is a complex pedagogical phenomenon that allows an active involvement of the students in the management of their independent work. This process in teaching foreign languages resulted in the outline of students' autonomy. Application of relative and half autonomy in combination with a firm and relatively firm teacher's guidance contribute to the successful development of lexical and grammatical competences in speaking of students of economics. Language portfolio as a tool of students' independent work can contribute to building the lexical and grammatical competences in speaking.

\section{References:}

Belgrad, S., Burke, K., \& Fogarty, R. (2008). Portfolio Connection: Student Work Linked to Standards. 3d ed. Thousand Oaks: SAGE Publications

Blidi, S. (2017). Collaborative Learner Autonomy: A Mode of Learner Autonomy Development. Singapore Springer Singapore Imprint: Springer. doi:10.1007/978-981-10-2048-3

Chan, V. (2003). Autonomous Language Learning: The teachers' perspectives. Teaching in Higher Education, 8(1), 33-54. doi: $10.1080 / 1356251032000052311$

Cooker, L. (2012). Formative (self-)assessment as autonomous language learning. Doctoral thesis, University of Nottingham, UK.

Delett, J. S., Barnhardt, S., \& Kevorkian, J. A. (2001). A Framework for Portfolio Assessment in the Foreign Language Classroom. Foreign Language Annals, 34(6), 559-568. doi:10.1111/j.1944-9720.2001.tb02103.x

Demirel, M. \& Duman, H. (2015). The Use of Portfolio in English Language Teaching and its Effects on Achievement and Attitude. Procedia - Social and Behavioral Sciences, 191, 2634-2640. doi:10.1016/j.sbspro.2015.04.598

Golubeva, M. G., Emelianova, N. A., Tuigunova, I. R., Egorova, O. G., \& Saveleva, U. A. (2019). The Implementation of CDIO Standards in the Context of 'TUNING' Approach when Training Teachers of Foreign Languages. The Journal of Teaching English for Specific and Academic Purposes, 7(4), 545-556. doi:10.22190/JTESAP1904545G

Holec, H. (1981). Autonomy and foreign language learning. Oxford, Pergamon.

Kamenskaia, L. S. (1999). Nekotorye voprosy organisatsii vneauditornoi samostoyatelnoi raboty studentov pri kommunikativnom obuchenii inostrannomu yazyku $\mathrm{v}$ neiazykovom vuze [Some issues of organisation of students' extracurricular and independent work with communicative teaching of foreign language in tertiary institutes]. Sbornik nauchnykh trudov MGLU, 437, 33-42.

Oxford, R. L. (2015). Expanded perspectives on autonomous learners. Innovation in Language Learning and Teaching, 9(1), 58-71. doi:10.1080/17501229.2014.995765

Tambovkina, T. Yu. (1998). K probleme avtonomii obuchaiushchikhcia inostrannomu yaziku v pedvuze [To the issue of autonomy of foreign language learners in pedagogical institues]. Inostrannye yazyki $v$ shkole, 4, 84-88.

Von Glasersfeld, E. (1989). Cognition, construction of knowledge, and teaching. Synthese, 80(1), 121-140. doi:10.1007/bf00869951

Wach, A. (2012). Computer-mediated communication as an autonomy-enhancement tool for advanced learners of English. Studies in Second Language Learning and Teaching, 2(3), 367-389. doi:10.14746/ssllt.2012.2.3.6

Hawkins, M. W. (2018). Self-directed learning as related to learning strategies, self-regulation, and autonomy in an English language program: A local application with global implications Studies in Second Language Learning and Teaching, 8(2), 445-469. doi:10.14746/ssllt.2018.8.2.12

White, C. (2008). Chapter 1: Language Learning Strategies in Independent Language Learning: An Overview. Language Learning Strategies in Independent Settings. In S. Hurd \& T. Lewis (Ed.), Language Learning Strategies in Independent Settings (pp. 3-24). Clevedon: Multilingual Matters. doi:10.21832/9781847690999-003

Zadorozhna, I. P. (2011). Organizatsiia samostiinoi roboty maibutnikh uchyteliv angliiskoimovy z praktychnoi movnoi pidgotovky [Organisation of future English language teachers' self-study work on practical language training]. Ternopil: TNPU.

Zadorozhna, I., Datskiv, O., \& Levchyk, N. (2018). Development of Pre-service Foreign Languages Teachers' Emotional Intelligence by Means of Reflection. Advanced Education, 10, 62-68. doi: 10.20535/2410-8286.144538 